\title{
Squamous Cell Carcinoma of the Suprapubic Cystostomy Tract With Bladder Involvement
}

\author{
Jae Min Chung, Jeong Hyun Oh, Su Hwan Kang, Seong Choi \\ Department of Urology, Kosin University College of Medicine, Busan, Korea
}

\begin{abstract}
Herein we report a case of a squamous cell carcinoma of a well-healed suprapubic cystostomy tract scar involving the bladder mucosa in a 56-year-old man. He presented with a spontaneous suprapubic urinary leak from a suprapubic cystostomy tract scar. He had a history of urethral stricture and failed urethroplasty. Preoperative cystoscopy suggested a bladder mass. Transurethral biopsy of the bladder mass revealed a squamous cell carcinoma confined to the suprapubic cystostomy tract involving the bladder mucosa. The patient died 6 months after the start of radiation therapy after lung metastasis and pneumonia.
\end{abstract}

Keywords: Cystostomy; Squamous cell carcinoma; Urinary bladder neoplasms

This is an Open Access article distributed under the terms of the Creative Commons Attribution Non-Commercial License (http://creativecommons.org/licenses/by-nc/3.0) which permits unrestricted non-commercial use, distribution, and reproduction in any medium, provided the original work is properly cited.

\author{
Article History: \\ received 27 January, 2012 \\ accepted 24 April, 2012
}

\author{
Corresponding Author: \\ Seong Choi \\ Department of Urology, Kosin \\ University College of Medicine, \\ 262 Gamcheon-ro, Seo-gu, Busan \\ 602-702, Korea \\ TEL: +82-55-990-5075 \\ FAX: +82-55-990-3994 \\ E-mail: schoi@ns.kosinmed.or.kr
}

\section{INTRODUCTION}

Most bladder squamous cell carcinomas have been described in paraplegics or in patients with spinal trauma. They are also known to occur in patients with long-term indwelling catheters and during chronic inflammatory states associated with frequent irritation and persistent infection. Here we report a case study of a patient who developed a squamous cell carcinoma involving the bladder mucosa from a well-healed suprapubic cystostomy scar after 9 years.

\section{CASE REPORT}

A 56-year-old male patient who had a suprapubic Foley catheter for 9 years after the formation of an urethrocutaneous fistula presented with a spontaneous suprapubic urinary leak from a well-healed suprapubic cystostomy tract scar. He originally had a urethral stricture that required multiple surgical corrections for 16 years beginning at the age of 28 years. Nineteen years later (at the age of 47 years), a urethrocutaneous fistula occurred spontaneously and a suprapubic cystostomy tube was eventually required for urinary diversion.

Physical examination revealed an erythematous lesion in the abdominal wall enveloping the suprapubic catheter.
The result of ThinPrep smear urine cytology was suspicious of malignancy. Cystoscopy revealed a bladder mass in the dome. Ultrasound examination of the kidneys did not show any dilatation. On the computed tomographic (CT) scan of the abdomen, a tumor mass surrounding the suprapubic cystostomy tract was clearly visible (Fig. 1). Transurethral biopsy of the bladder mass was performed. Histological examination of the biopsy from the bladder mass revealed squamous cell carcinoma, moderately differentiated, probably originating from the vesicocutaneous fistula tract involving the bladder mucosa (Fig. 2).

The patient did not want to undergo aggressive surgical excision of the complete bladder and the abdominal wall and underwent radiation therapy. Although a CT scan of the abdomen after radiation therapy showed partial remission (Fig. 3), the patient died of lung metastasis and pneumonia at 6 months after the start of radiation therapy.

\section{DISCUSSION}

Squamous cell carcinoma is a rare form of carcinoma of the bladder that accounts for only $5 \%$ of such carcinomas [1]. It is usually caused by chronic irritation from urinary calculi, long-term indwelling catheters, chronic urinary infections, or bladder diverticula. As many as $80 \%$ of paraplegics with chronic infections or indwelling catheters ex- 


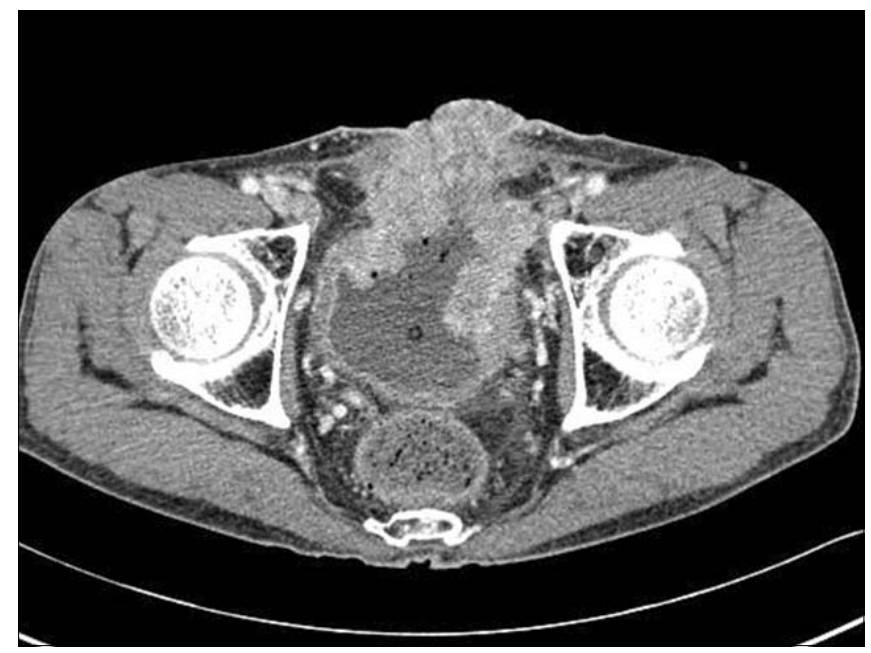

FiG. 1. Computed tomography of the abdomen showing the catheter in the bladder below a tumor mass encasing the catheter as it passes through the abdominal wall.

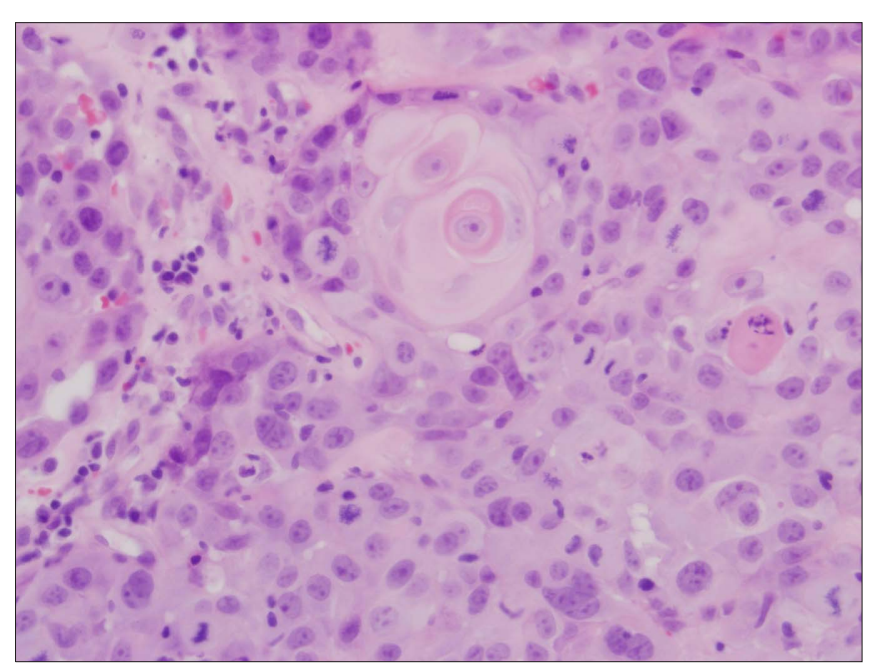

Fig. 2. The pathologic features of the tumor mass $(H \& E, \times 200)$. The microphotograph showed an invasive squamous cell carcinoma with well-differentiated mature squamous cells and abundant keratin pearls and occasional well-developed intercellular bridges.

perience squamous changes in the bladder, and about $5 \%$ develop squamous cell carcinoma [2]. Cigarette smoking is also significantly associated with an increased risk of bladder squamous cell carcinoma [3]. Male predominance is far less striking in squamous cell carcinoma (male to female ratio, $1.3: 1$ to $1.7: 1$ ) [4].

There are only four case reports of suprapubic catheter tract squamous cell carcinoma (two of them involving the bladder) in the English literature [5-8]. The case reported here is the third case of suprapubic catheter tract squamous cell carcinoma extending into the bladder. We present the published cases of suprapubic catheter tract squamous cell carcinoma in Table 1 .

The prolonged presence of a tube with continuous irrita-

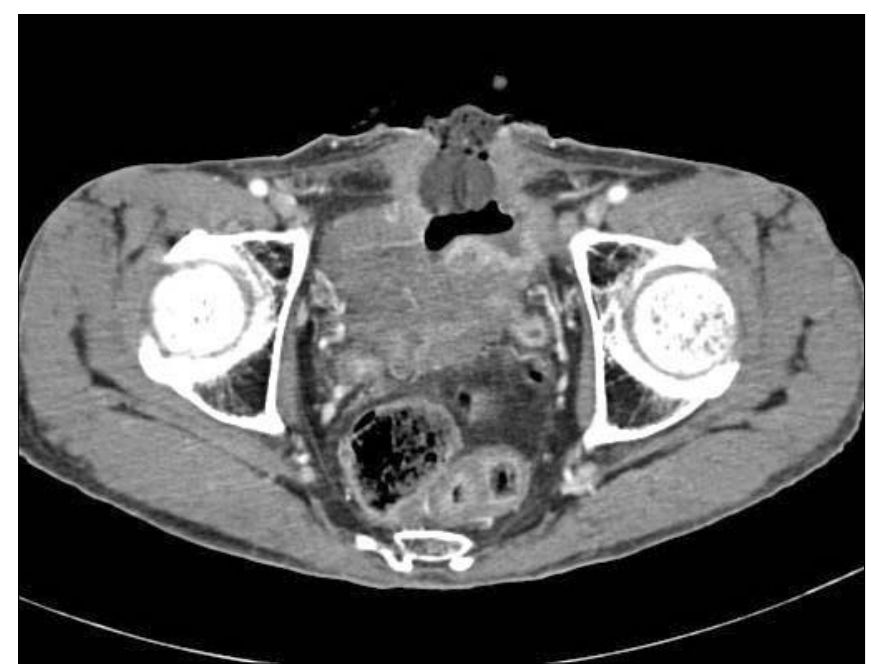

FiG. 3. Computed tomography of the abdomen after radiation therapy showing partial remission.

tion of the tract site leading to metaplasia and carcinoma provides a possible mechanism for carcinoma [6]. In the literature, a $10 \%$ incidence of squamous cell carcinoma of the bladder has been noted in patients who have had indwelling catheters for more than 10 years [5]. Kaufman et al. [9] found that spinal cord injury patients who have had indwelling catheters for more than 10 years have a $20 \%$ prevalence of squamous cell carcinoma of the bladder, and those authors advocated for periodic cystoscopies combined with random bladder biopsies for this category of patients.

Because this type of cancer is extremely rare, insufficient experience exists to postulate the etiology in cases that present several years later in a well-healed suprapubic catheter tract site. Persistent discharge is often attributed to recurrence of stricture, for which cystostomies are frequently performed, leading to missed malignancies. These lesions are usually localized and are best treated by radical excisional surgery because of the rapid death of conservatively treated patients [1]. Bladder involvement generally dictates surgical management because long-term survival benefits resulting from radiotherapy or chemotherapy have not been reported to date [8].

However, the patient in our study chose not to undergo planned aggressive surgical excision of the complete bladder and the abdominal wall and was instead treated with radiation therapy. He died 6 months after the start of radiation therapy owing to lung metastasis and pneumonia.

Several reports suggest that the stage-by-stage prognosis of squamous cell carcinoma is comparable to that of transitional cell carcinoma [10]. The prognosis of suprapubic catheter tract squamous cell carcinoma is comparatively poor because most patients have advanced disease at the time of diagnosis.

In conclusion, persistent discharge from a well-healed suprapubic catheter scar site several years after a cystostomy should be grounds for suspicion of this rare clinical 
TABLE 1. Published cases of squamous cell carcinoma of the suprapubic cystostomy tract

\begin{tabular}{|c|c|c|c|c|c|c|c|}
\hline $\begin{array}{c}\text { Published } \\
\text { year }\end{array}$ & Author & Age (y) & $\begin{array}{c}\text { Duration } \\
\text { suprapubic } \\
\text { cystostomy (y) }\end{array}$ & $\begin{array}{c}\text { Bladder } \\
\text { involvement }\end{array}$ & $\mathrm{T}$ stage & Treatment & Survival \\
\hline 2013 & Present study & 56 & 9 & $(+)$ & $\mathrm{T} 4$ & Radiation & $\begin{array}{l}\text { Dead at } 6 \text { months } \\
\text { after radiation }\end{array}$ \\
\hline 2000 & Gupta et al. [8] & 40 & 20 & $(+)$ & $\mathrm{T} 4$ & $\begin{array}{l}\text { Radical cystoprostatectomy, } \\
\text { en bloc pubectomy and } \\
\text { excision mass with ileal } \\
\text { conduit }\end{array}$ & $\begin{array}{l}\text { Survival at a } \\
\text { follow-up of } 3 \\
\text { months }\end{array}$ \\
\hline 1999 & Schaafsma et al. [7] & 80 & 5 & $(-)$ & $\mathrm{T} 4$ & $\begin{array}{l}\text { Wide excision of mass and } \\
\text { partial cystectomy }\end{array}$ & $\begin{array}{l}\text { Dead at } 5 \text { months } \\
\text { after surgery }\end{array}$ \\
\hline 1995 & Stokes 3rd et al. [6] & 50 & 25 & $(+)$ & $\mathrm{T} 4$ & Excision & $\begin{array}{l}\text { Dead at } 8 \text { months } \\
\text { after surgery }\end{array}$ \\
\hline 1993 & Stroumbakis et al. [5] & 80 & 5 & $(-)$ & & Radiation and excision & Not described \\
\hline
\end{tabular}

entity, and an excisional biopsy should always be performed, especially when no stricture or bladder pathology is detectable on cystoscopy. This case study underscores the need for close monitoring of patients with any type of long-term indwelling catheter.

\section{CONFLICTS OF INTEREST}

The authors have nothing to disclose.

\section{REFERENCES}

1. Rous SN. Squamous cell carcinoma of the bladder. J Urol 1978; 120:561-2.

2. Bahnson RR. Squamous cell carcinoma of bladder. J Urol 1997; 157:2115.

3. Kantor AF, Hartge P, Hoover RN, Fraumeni JF Jr. Epidemiological characteristics of squamous cell carcinoma and adenocarcinoma of the bladder. Cancer Res 1988;48:3853-5.
4. Lynch CF, Cohen MB. Urinary system. Cancer 1995;75(1 Suppl): 316-29.

5. Stroumbakis N, Choudhury MS, Hernandez-Graulau JM. Squamous cell carcinoma arising from suprapubic cystotomy site without bladder involvement. Urology 1993;41:568-70.

6. Stokes S 3rd, Wheeler JS Jr, Reyes CV. Squamous cell carcinoma arising from a suprapubic cystostomy tract with extension into the bladder. J Urol 1995;154:1132-3.

7. Schaafsma RJ, Delaere KP, Theunissen PH. Squamous cell carcinoma of suprapubic cystostomy tract without bladder involvement. Spinal Cord 1999;37:373-4.

8. Gupta NP, Singh I, Nabi G, Ansari MS, Mandal S. Marjolin's ulcer of the suprapubic cystostomy site infiltrating the urinary bladder: a rare occurrence. Urology 2000;56:330.

9. Kaufman JM, Fam B, Jacobs SC, Gabilondo F, Yalla S, Kane JP, et al. Bladder cancer and squamous metaplasia in spinal cord injury patients. J Urol 1977;118:967-71.

10. Johnson DE, Schoenwald MB, Ayala AG, Miller LS. Squamous cell carcinoma of the bladder. J Urol 1976;115:542-4. 